\title{
ФАРМАКОЛОГИЧЕСКИЕ ЭФФЕКТЫ ДИБОРНОЛА-ГЭК ПРИ ТОТАЛЬНОЙ ТРАНЗИТОРНОЙ ИШЕМИИ У КРЫС
}

О.И. Алиев', А.В. Сидехменова', А.М. Анищенко', Г.А. Чернышева', В.И. Смольякова', А.В. Кучин ${ }^{2}$, И.Ю. Чукичева², М.Б. Плотников'

${ }^{1}$ Лаборатория фармакологии кровообращения, НИИФиРМ им. Е.Д. Гольдберга Томского НИМЦ РАН, 634028, Россия, Томск, пр. Ленина,3.

2Лаборатория органического синтеза и химии природных соединений, Институт химии Коми НЦ УрО РАН, 167000, Россия, Республика Коми, г. Сыктывкар, ул. Первомайская, 48.

DOI: 10.19163/MedChemRussia2021-2021-138

E-mail: oal67@yandex.ru

За последние годы во всем мире проведено большое количество экспериментальных и клинических исследований, доказавших участие сдвигов реологических свойств крови в развитии и течении острых нарушений мозгового кровообращения. Вместе с тем, в настоящее время отсутствует специфическая фармакотерапия, направленная на коррекцию нарушений реологических свойств крови в острейший период нарушений мозгового кровообращения. Цель работы - доклинические исследования лекарственного средства гемореологического действия на основе 2,6-диизоборнил-4метилфенола и гидроксиэтилированного крахмала (диборнол-ГЭК).

Проведенные на моделя in vitro исследования показали, что диборнолГЭК ограничивает возрастание вязкости крови в широком диапазоне скоростей сдвига и снижает фибриноген зависимую агрегацию эритроцитов. Диборнол-ГЭК проявляет антирадикальную активность в системе с водорастворимым радикалом ABTS+ и в суспензии эритроцитов снижает накопление продуктов перекисного окисления липидов.

На модели тотальной транзиторной ишемии головного мозга внутривенное введение диборнола-ГЭК повышает уровень локального мозгового кровотока в коре больших полушарий головного мозга, уменьшает проявление синдрома повышенной вязкости крови за счет снижения вязкости крови в диапазоне высоких скоростей сдвига и ограничивает гиперагрегацию эритроцитов, как в стационарных условиях, так и в сдвиговом потоке. Кроме того, диборнол-ГЭК, повышает выживаемость животных и снижает выраженность неврологического дефицита после эпизода тотальной ишемии головного мозга с последующей реперфузией.

Таким образом, диборнол-ГЭК является перспективным соединением для разработки на его основе средства комплексной терапии острых ишемических нарушений кровообращения. 